\title{
Serum thyroxine and thyroid stimulating hormone concentrations after treatment of congenital hypothyroidism
}

\author{
S S A ABUSREWIL, L TYFIELD, AND D C L SAVAGE
}

Bristol Royal Hospital for Sick Children and the Regional Screening Laboratory, Southmead Hospital, Bristol

SUMMARY Serum thyroid stimulating hormone and thyroxine concentrations were monitored in 42 infants who had been treated for congenital hypothyroidism. Serum thyroid stimulating hormone concentrations were raised in 22 of the infants $(52 \%)$ at 2 to 4 months, in $16(38 \%)$ at 5 to 11 months, in $14(33 \%)$ at 12 to 18 months, and in eight $(19 \%)$ at 2 to 4 years. Serum thyroxine and the dose of L-thyroxine $/ \mathrm{kg} /$ body weight were significantly lower in those infants with raised thyroid stimulating hormone concentrations. Thyroid stimulating hormone was appropriately suppressed when the dose of L-thyroxine was increased, and only one child had delayed maturation of the hypothalamic/pituitary/thyroid axis. We believe it is the infant's rapid gain in weight in the first two years of life that necessitates this decrease in the dose of L-thyroxine $/ \mathrm{kg}$ body weight and recommend that the treatment of this age group is reviewed every two to three months.

Screening programmes for congenital hypothyroidism were first reported in $1975^{12}$ and are now practised in many countries. Initial reports confirmed their efficacy and detailed the children's normal growth and development, ${ }^{3-5}$ though recent studies have suggested that these children may not perform as well as normal controls. ${ }^{6-8}$ This may reflect inadequate treatment and it is unfortunate that there are few reports ${ }^{9-11}$ and only one longitudinal study ${ }^{12}$ that have examined the serum thyroxine concentrations after treatment.

We now report plasma thyroid stimulating hormone and thyroxine concentrations after replacement treatment in children detected in the congenital hypothyroid screening programme in the South West region of England between 1981 and 1986. We have correlated these concentrations with the dose of L-thyroxine $/ \mathrm{kg}$ body weight in an attempt to calculate optimal dosage regimens.

\section{Patients and methods}

The infants screened were those born in the South West region of England from 1981 to 1986 . Capillary blood samples for the measurement of thyroid stimulating hormone were collected in duplicate on filter paper when babies were 7 days old and sent to the regional screening laboratory at Southmead Hospital, Bristol. Thyroid stimulating hormone was measured by an immunoradiometric assay (sensitivity $8 \mathrm{mU} / \mathrm{l}$, interassay variation $12 \%$ ). A blood spot thyroid stimulating hormone concentration of $<25$ $\mathrm{mU} / \mathrm{l}$ was regarded as normal; a concentration of $>80 \mathrm{mU} / \mathrm{l}$ was considered abnormal and infants were referred to a local paediatrician for clinical assessment and further biochemical investigations. Repeat blood spots were requested on neonates whose blood spot thyroid stimulating hormone concentrations were in the range 25 to $80 \mathrm{mU} / \mathrm{l}$. If the blood spot thyroid stimulating hormone was $>25 \mathrm{mU} / \mathrm{l}$ on repeat analysis the infant was referred to a local paediatrician for further investigations. The Medical Research Council definition of congenital hypothyroidism was adopted. This comprises a plasma or serum total thyroxine concentration by quantitative analysis of less than 65 $\mathrm{nmol} / \mathrm{l}$, or a plasma or serum thyroid stimulating hormone concentration by quantitative analysis of more than $10 \mathrm{mU} / \mathrm{l}$

Treatment with L-thyroxine and the children's progress were supervised by the local paediatricians. Treatment was monitored by the filter paper capil- 
lary blood assay for thyroid stimulating hormone. If the blood spot thyroid stimulating hormone concentrations were higher than the detection limit of the assay $(8 \mathrm{mU} / \mathrm{l})$, paediatricians were advised to check the plasma or serum concentrations of thyroxine and thyroid stimulating hormone.

We identified through the screening laboratory all children with raised serum or plasma thyroid stimulating hormone concentrations (that is, $>10 \mathrm{mU} / \mathrm{l}$ ) and extracted clinical and biochemical data and treatment regimens from their hospital case notes. The data were analysed by comparing those with raised plasma thyroid stimulating hormone concentrations with those with normal concentrations. Comparison of the serum thyroxine concentrations and doses of L-thyroxine between the two groups was by the Mann-Whitney test and Student's $t$ test, respectively. Statistical analysis was done of the pooled results and of the results at different ages.

\section{Results}

The population of the south west of England is roughly three million, and the annual birth rate about 37000 , and 185723 infants $(99 \%$ of all newborn babies) were screened between 1981 and 1986. The recall rate for a repeat sample was $0 \cdot 11 \%$.

Forty two infants (16 boys and 26 girls) had primary congenital hypothyroidism according to the Medical Research Council definition. The incidence is $1: 4400$. Seven other infants (five boys, two girls) had raised plasma thyroid stimulating hormone concentrations and total thyroxine concentrations within the normal range (all were more than $100 \mathrm{nmol} / \mathrm{l})$. Three have subsequently become hypothyroid (unpublished observations).

The mean age at diagnosis was $\mathbf{1 3 . 8}$ days (range 9-18), that at starting treatment was 16 days (range 9-38), and that at the time of study was 31.5 months (range 6-63).

After treatment the serum thyroid stimulating hormone concentrations were raised in 22 of the infants $(52 \%)$ between 2 and 4 months, in $16(38 \%)$ between 5 and 11 months, in $14(33 \%)$ between 12 and 18 months, and in eight (19\%) between 2 and 4 years. Serum thyroxine concentrations were never below the normal range for age throughout the study period but were significantly lower in the infants with raised thyroid stimulating hormone concentrations ( $p<0.0001)$ (fig 1 and table). Only one infant had persistently raised thyroid stimulating hormone concentrations in the presence of serum thyroxine concentrations in the upper part of the normal range and a satisfactory thyroxine dose/kg body weight (described as 'delayed maturation' in the figures). In all other instances thyroid

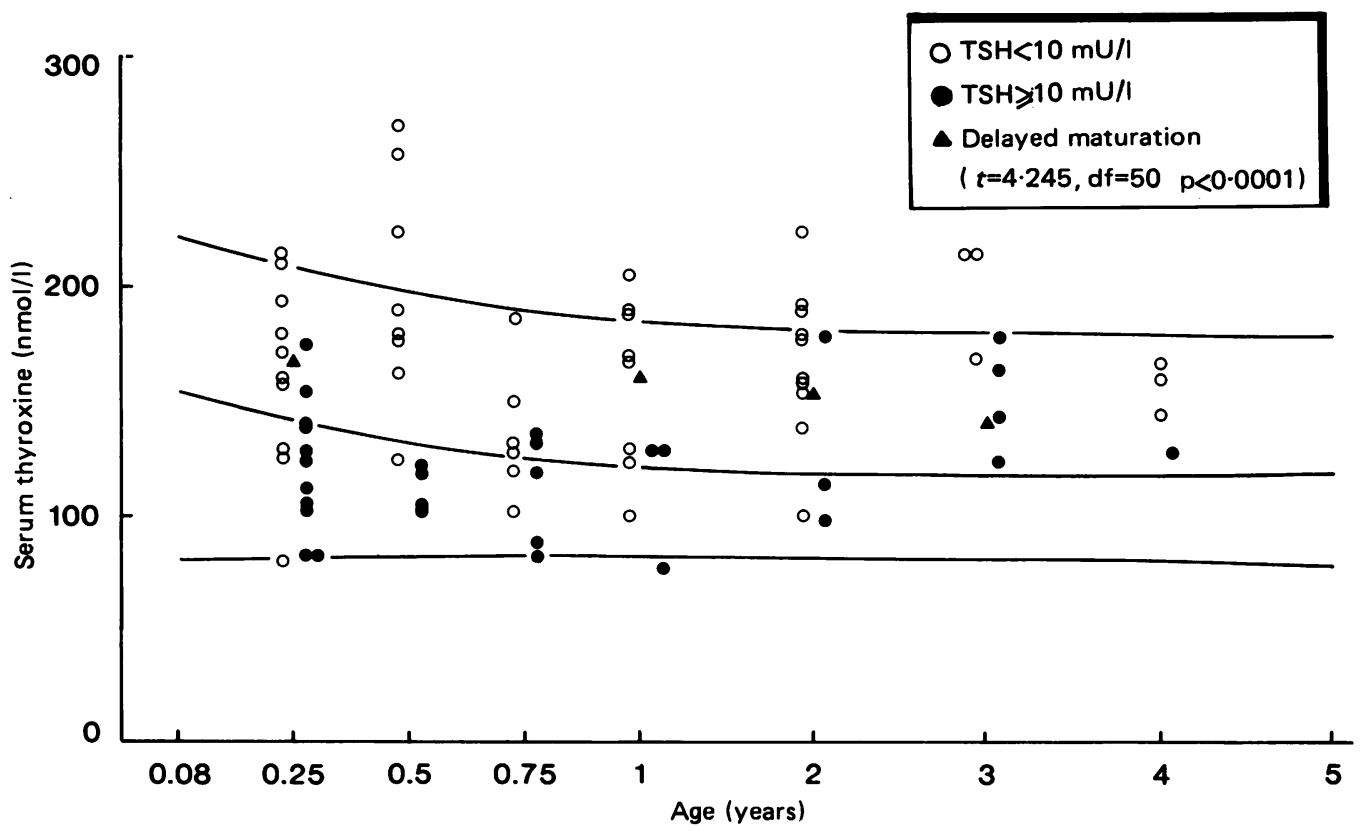

Fig 1 Serum thyroxine concentrations in children with normal or raised thyroid stimulating hormone. 
Table Mean serum thyroxine concentrations (nmolll) in children with normal or raised thyroid stimulating hormone (TSH) concentrations during the study

\begin{tabular}{|c|c|c|}
\hline \multirow[t]{2}{*}{ Age (years) } & \multicolumn{2}{|c|}{ Mean TSH concentration $(m U / l)$} \\
\hline & $<10$ & $\geqslant 10$ \\
\hline 0.25 & 165 & 120 \\
\hline 0.5 & 198 & 111 \\
\hline 0.75 & 148 & 111 \\
\hline 1 & 160 & 113 \\
\hline 2 & 166 & 122 \\
\hline 3 & 199 & 152 \\
\hline 4 & 159 & 128 \\
\hline
\end{tabular}

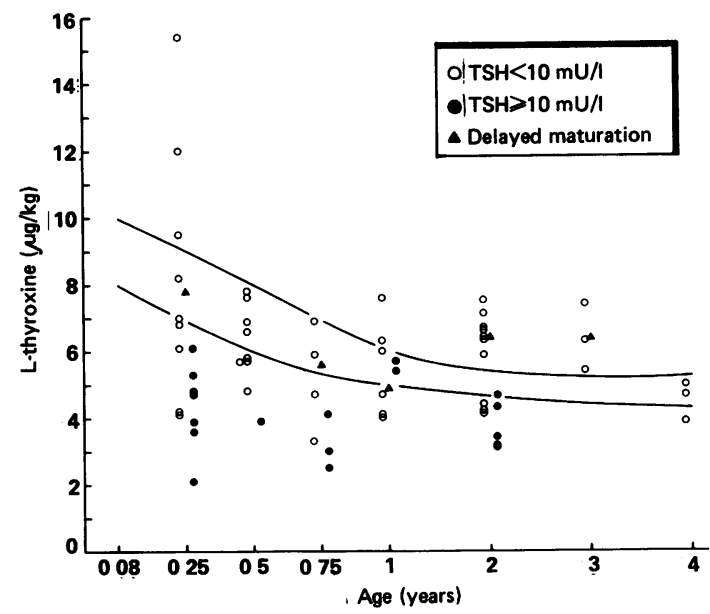

Fig 2 L-thyroxine dosage ( $\mu \mathrm{g} / \mathrm{kg} /$ body weight) in children with normal or raised serum thyroid stimulating hormone concentrations.

stimulating hormone was normally reduced when the dose of L-thyroxine was appropriately increased.

The dose of L-thyroxine/kg body weight varied widely at all ages throughout the study period but this was most pronounced in early infancy. The mean L-thyroxine doses/ $\mathrm{kg}$ body weight were significantly lower in infants with raised thyroid stimulating hormone concentrations $(p<0 \cdot 0001)$ (fig 2$)$.

The growth and development of all the children were recorded as normal.

\section{Discussion}

Our results confirm those of earlier studies that showed that serum thyroid stimulating hormone concentrations remain raised in a number of chil- dren who have been treated for congenital hypothyroidism. 9101112

The only study comparable with our own ${ }^{12}$ reported that one third of 36 infants treated for congenital hypothyroidism had raised serum thyroid stimulating hormone concentrations at 1 year of age. The authors observed that those children with raised thyroid stimulating hormone concentrations had lower serum thyroxine concentrations and had received lower doses of L-thyroxine/kg body weight. They suggested that the raised thyroid stimulating hormone concentrations was due either to an alteration in the set point of reduction, or to under treatment.

Other reports are less comprehensive. Sato et al studied nine children with athyrotic or ectopic hypothyroidism diagnosed between 6 months and 17 years of age. They defined euthyroidism as a basal thyroid stimulating hormone concentration of $<10 \mathrm{mU} / 1$ and a normal thyroid stimulating hormone response to thyrotrophin releasing hormone, and concluded that the pituitary threshold for regulation of thyroid stimulating hormone release by thyroxine is higher in infants and young children, and gradually decreases over several years. They recommended that the dose of L-thyroxine $/ \mathrm{kg}$ body weight should be comparatively higher in infancy and decrease through childhood.

Schultz et al $^{10}$ reported five infants with congenital hypothyroidism and persistently raised thyroid stimulating hormone concentrations up to 24 months of age. The dose of L-thyroxine was appropriate, though in the lower half of the recommended range for age in four of the infants, and inadequate in the fifth. Serum thyroxine was measured on 34 occasions and all but one were within the lower range of normal. Thyroid stimulating hormone was normally reduced in four infants when their serum thyroxine concentrations rose into the upper range of normal. Schultz et al suggested that the hypothalamic/pituitary threshold for reduction of thyroid stimulating hormone is unusually high in infancy and their data confirm the need for serum thyroxine to be kept in the upper range of normal.

Our results show that although serum thyroxine concentrations were within the normal range for age for all the children, there was a negative correlation between their serum thyroid stimulating hormone and thyroxine concentrations and their serum thyroid stimulating hormone and thyroxine dose when expressed by kilogram body weight. Individually, when their thyroxine doses were increased their serum thyroid stimulating hormone concentrations were normally reduced. We believe that it is the infants' rapid increase in body weight that provokes 
this decrease in the prescribed dose of L-thyroxine/ $\mathrm{kg}$ body weight so that serum thyroxine concentrations fall and thyroid stimulating hormone concentrations rise.

A number of reports have confirmed that the dose of thyroxine/ $\mathrm{kg}$ body weight is high in infancy and decreases through childhood into adult life. ${ }^{13} 1415$ These recommended doses range from $8-10 \mu \mathrm{g} / \mathrm{kg}$ in infancy to $5-6 \mu \mathrm{g} / \mathrm{kg}$ in early childhood, and fall to $3-4 \mu \mathrm{g} / \mathrm{kg}$ in later childhood. Our data confirm these doses.

Some authors believe that delayed maturation of the hypothalamic/pituitary/thyroid axis is the reason for the persistently raised thyroid stimulating hormone concentrations in early childhood in children treated for congenital hypothyroidism. We believe that this is rare, and the term should be limited to those infants in whom appropriate doses of Lthyroxine are given, in whom serum thyroxine is persistently in the upper range of normal, and in whom the thyroid stimulating hormone remains raised. Only one infant in our study fulfilled these criteria.

Our data confirm that a raised thyroid stimulating hormone concentration after treatment for congenital hypothyroidism generally denotes undertreatment. A similar conclusion was reached by Frost and Parkin in a study in older children, $22 \%$ of whom had raised thyroid stimulating hormone concentrations and were receiving inappropriate treatment. $^{16}$

There is some evidence that infants apparently being adequately treated for congenital hypothyroidism do not perform as well as controls. ${ }^{5-8}$ Whether this is due to events before or after birth is unknown, but it does reinforce the need for careful surveillance of the children's treatment. We recommend that the infants are reviewed every two months during the first year of life when body weight is increasing rapidly. Then if the serum thyroid stimulating hormone is raised the serum thyroxine must be checked and the dose of Lthyroxine increased to maintain it in the upper range of normal. If this is done it will prevent undertreatment and the inappropriate diagnosis of delayed maturation of the hypothalamic/pituitary/ thyroid axis.
We thank the paediatricians in the South West region for their help.

\section{References}

${ }^{1}$ Dussalt JH, Coulombe P, Loberge C, Letarte J, Guyda H, Khoury K. Preliminary report on a mass screening program for neonatal hypothyroidism. J Pediatr 1975;86:670-4.

2 Klein AH, Agustin AV, Foley TP Jr. Successful laboratory screening for congenital hypothyroidism. Lancet 1974;ii:77-9.

${ }^{3}$ Klein AH, Meltzer S, Kenny FM. Improved prognosis in congenital hypothyroidism treated before age three months. J Pediatr 1972;81:912-5.

${ }^{4}$ Macfaul R, Dorner S, Brett EM, Grant DB. Neurological abnormalities in patients treated for hypothyroidism for early life. Arch Dis Child 1978;53:611-9.

5 Glorieux J, Dussault JH, Letarte J, Guyda H, Morissette J. Preliminary results on the mental development of hypothyroid infants detected by the Quebec screening program. J Pediatr 1983;102:19-22.

6 Glorieux J, Dussault JH, Morissette J, Desjardins J, Letarte JD, Gudya H. Follow up at ages 5 and 7 years on mental development in children with hypothyroidism detected by Quebec screening program. J Pediatr 1985;107:913-5.

${ }^{7}$ Rover JF, Westbrook D, Ehlick RM. Neonatal thyroid deficiency early temperamental and cognitive characteristics. J Am Acad Child Psychiatry 1984;23:10-2.

${ }^{8}$ Murphy G, Hulse JA, Jackson D, et al. Early treated hypothyroidism: development at 3 years. Arch Dis Child 1986;61:761-5.

9 Sato T, Suzuki Y, Taketani T, Ishiguro K, Nakajima H. Age related change in pituitary threshold for TSH release during thyroxine replacement therapy for cretinism. J Clin Endocrinol Metab 1977;44:553-9.

${ }^{10}$ Schultz RM, Glassman MS, MacGillivary MH. Elevated threshold for thyrothropin suppression in congenital hypothyroidism. Am J Dis Child 1980;134:19-20.

11 Sokya LF, Redmond GP. Problems in the treatment of neonates with genetic diseases of the thyroid. Proceedings of the second international clinical genetics seminar. New York: Alan R Liss, 1979;331-42.

12 Hulse JA, Grant DB, Jackson D, Clayton BE. Growth, development and reassessment of hypothyroid infants diagnosed by screening. Br Med J 1982;284:1435-7.

13 Abbassi V, Aldige C. Evaluation of sodium L-thyroxine (T4) requirement in replacement therapy of hypothyroidism. J Pediatr 1977;90:298-301.

14 Rezvani I, DiGeorge AM. Reassessment of the daily dose of oral thyroxine for replacement therapy in hypothyroid children. J Pediatr 1977;90:291-7.

15 Desai M, Iran AJ, Raikan RS, et al. Therapy of childhood hypothyroidism. A reappraisal. Indian Pediatr 1982;19:927-36.

${ }^{16}$ Frost GJ, Parkin JM. Management of patients with congenital hypothyroidism. Br Med J 1985;290:1485-9.

Correspondence to Dr DCL Savage, Bristol Royal Hospital for Sick Children, St Michael's Hill, Bristol BS2 8BJ.

Accepted 14 June 1988 